\title{
EDITORIAL
}

\section{Visibilidades e invisibilidades midiáticas}

A edição de RuMoRes, revista científica online dedicada aos estudos de comunicação, linguagem e mídias, em seu número 15, correspondente ao primeiro semestre de 2014, concentra-se em torno do tema da invisibilidade nas mídias, colocando uma dupla questão: como ela pode ser circundada conceitualmente e quem são seus personagens e atributos. Temos, assim, o prazer de apresentar, no Dossiê, diversos artigos reunidos em torno da temática "A visibilidade dos anônimos", resultante do seminário homônimo realizado pelo Grupo de Pesquisa Mídia e Narrativa, da PUC Minas, em novembro de 2013, sob a coordenação de Marcio Serelle.

Acreditamos que abordar a problemática da invisibilidade, mais do que dedicar-se a um tema periférico nos estudos das mídias, é identificar sua própria dinâmica de funcionamento. Ela envolve a negociação com sistemas de visibilidade e também com as formas de representação nos registros ficcional e factual. Ademais, como está ressaltado na Apresentação do referido Dossiê, vivemos um momento de debate sobre a distribuição de lugares midiáticos na contemporaneidade, estabelecendo novos regimes de visibilidade.

Iniciando a seleção de artigos do Dossiê, Vera Follain de Figueiredo navega sobre a dicotomia visibilidade/invisibilidade pensando como ela se torna mais tênue com o avanço das tecnologias de comunicação. Marcio Serelle, por sua vez, recupera narrativas em que a visibilidade acede numa "forma bastarda", gênero híbrido entre ficção e narração dos fatos. Do bastardo ao malandro, Samuel Paiva retoma o ensaio "Dialética da malandragem" (1970), de Antônio Cândido, para atualizar o conceito de malandragem visto em filmes de estrada nacionais.

Glória Gomide também faz um movimento de recuperação histórica, voltando à obra Os miseráveis, de Victor Hugo, para ecoá-la hoje sobre 
personagens identitariamente abafados numa dispersão coletiva. Outra figura, trazida por Lígia Lana para o debate, é a personagem da "periguete". Revelada em telenovelas brasileiras, sua presença é descrita envolvendo a diferença de classes e a possibilidade de ascensão a uma das possibilidades do visível. Mário Viggiano também identifica no programa humorístico televisivo "Pé na cova" a necessidade de problematizar a presença de personagens em regimes de (in) visibilidade, constantes na trama do programa.

Do trabalho com registros mais ficcionais e artísticos, a dualidade visibilidade/invisibilidade também é abordada em relatos que se anunciam mais comprometidos com os fatos, com o tempo presente e com os movimentos políticos. Ercio Sena percorre a trilha dos cartazes erguidos durante as manifestações de junho no país, considerando especialmente aquelas ocorridas na cidade de Belo Horizonte. Carlos Henrique Pinheiro, por sua vez, volta-se para as narrativas da grande imprensa observando como se dá a entrada nelas por parte de membros de movimentos sociais destacados socialmente e na dinâmica com a imprensa. Crescendo em gradação no quesito visibilidade midiática, Fernanda Medeiros vai em busca de analisar a participação de celebridades que, desta posição, manifestaram apoio aos protestos. Está em jogo a forma de relato sobre uma movimentação social, a partir da qual Pedro Vaz Perez retoma o filme $A b c$ da greve, de Leon Hirszman, analisando a forma de conceituação de produção de um ensaio documental político.

No corpo da edição temos com artigos alinhados ao relevante debate. Sandra Fischer faz um percurso tangenciando um deslugar, como forma ao mesmo tempo subjetiva e objetiva de estar no mundo, considerando os filmes O palhaço (2011) e Um lugar qualquer (2010). Monica Martinez, por sua vez, volta-se às possibilidades de letramento digital para aqueles com mais de 60 anos, como público demandante de voz e visibilidade social.

Renata Tomaz apropria-se das diferenças entre a personagem Alice, de Lewis Carroll, e aquela de Tim Burton como uma base para discutir questões da identidade na modernidade. O olhar de cineastas latinoamericanos para questões 
sociais é apresentado por Natalia Barrenha através documentário venezuelano Araya (1959), referindo-se também a uma questão presente em diversos textos da edição que atentam para a forma do relato documental. Finalizando a edição, Patrícia Schuster se volta às metáforas presentes nos textos de Veja observando de que modo elas enredam um sentido visível nas reportagens da revista.

Esta edição de RuMoRes realiza ainda uma homenagem a duas pessoas especiais que nos deixaram recentemente. Não temos mais conosco a querida amiga e integrante da comissão editorial, Paula Paschoalick, participante ativa da equipe deste periódico desde sua criação, e responsável pelo desenvolvimento e gerenciamento do site. Relembramos também o inestimável professor Eduardo Peñuela Cañizal por suas grandes contribuições na área dos estudos de imagem e pela formação de diversas gerações de pesquisadores, que certamente refletem na linha editorial desta publicação. A eles dedicamos esta edição e deixamos nossas saudades. Ambos nos farão irreparável falta. 